\title{
Evaluation of True Seed Shallot Varieties for Yield and Yield Components
}

\author{
Dasta Tsagaye $^{1, ~}{ }^{*}$, Awoke Ali ${ }^{1}$, Gizaw Wegayehu ${ }^{1}$, Fekadu Gebretensay $^{2}$, Nimona Fufa $^{1}$, Demis Fikre $^{1}$ \\ ${ }^{1}$ Ethiopian Institute of Agricultural Research, Kulumsa Agricultural Research Center, Asella, Ethiopia \\ ${ }^{2}$ Ethiopian Institute of Agricultural Research, Debre - Zeit Agricultural Research Center, Bishoftu, Ethiopia
}

Email address:

6dasta2@gmail.com (D. Tsagaye)

${ }^{*}$ Corresponding author

\section{To cite this article:}

Dasta Tsagaye, Awoke Ali, Gizaw Wegayehu, Fekadu Gebretensay, Nimona Fufa, Demis Fikre. Evaluation of True Seed Shallot Varieties for Yield and Yield Components. American Journal of Plant Biology. Vol. 6, No. 1, 2021, pp. 19-22. doi: 10.11648/j.ajpb.20210601.13

Received: December 21, 2020; Accepted: April 14, 2021; Published: April 26, 2021

\begin{abstract}
Shallot (Allium cepa var. ascalonicum Backer) is an important vegetable crop cultivated by smallholder farmers for consumption and income generation in Ethiopia. However, scarcity of high yielding varieties as well as lack of superior planting material seriously constrains productivity of the crop. Research project was initiated aiming at studying adaption of true seed shallot for yield and components. A series of experiments were conducted using the randomized complete block design to identify the appropriate variety for production of bulb yield. The combined analysis of variance results for marketable bulb yield (kg/plot), unmarketable bulb yield $(\mathrm{kg} / \mathrm{ha})$, total bulb yield $(\mathrm{kg} / \mathrm{plot})$ and total bulb yield $(\mathrm{t} / \mathrm{ha})$. The results showed that the mean squares for main factors of genotype and year as well as interaction of genotypes $\mathrm{x}$ year were significant for marketable bulb yield ( $\mathrm{kg} / \mathrm{plot})$. The overall marketable yield range of the shallot varieties was from 256.56$171.49 \mathrm{qtha}^{-1}$ and the average number of splits per plants ranged from 8- 4.72. Improved Minjar shallot variety showed its superiority in marketable bulb yield $(\mathrm{kg} / \mathrm{plot})$, total bulb yield $(\mathrm{kg} / \mathrm{plot})$ and total bulb yield $(\mathrm{t} / \mathrm{ha})$ yields as compared to other varieties. Therefore, as there was no significant yield advantage between these varieties from true seed study area, so the experiment could be repeated across locations to come up with good conclusion for recommendation.
\end{abstract}

Keywords: Shallot, Varieties, True Seed, Yield

\section{Introduction}

Shallot (Allium cepa var ascalonicum Baker) is an important vegetable crop cultivated in many tropical countries as a substitute for bulb onions (Allium cepa L. var сера) [1]. Farmers in tropical countries preferred shallots than onion for its ability to propagate vegetatively, shorter growth cycle, better tolerance to disease and drought stresses and longer storage life than the common onion and for their distinct flavor that persists after cooking [2, 3].

In Ethiopia, shallot is produced mostly at highland areas under rain-fed conditions by smallholder farmers as an income generating spice crop mainly used as condiment in Ethiopian traditional food $[4,1]$. Besides that, the crop is widely adapted to different climatic and edaphic condition and is cultivated both under rain-fed and irrigated conditions [5]. According to Kebede Woldetasdik, [5] the crop is produced traditionally by small farmers in Hararge, Shoa, Arsi, Gojjam, etc. as cash crops and income generating spices for flavoring local dishes. Shallot (Allium cepa L. aggregatum group) is the favourite and a widely grown condimental crop in Ethiopia. It is used daily in almost every house as a seasoning spice in the preparation of local dishes such as Wot (a stew) eaten with Injera (Ethiopian fluffy bread) [6]. Shallot is also preferred for its shorter growth cycle, better tolerance to disease and drought stresses and longer storage life than the common onion and for its distinct flavor that persists after cooking. In Ethiopia, the production of shallot was 132424.68 ton in 14758.51 ha of land with an average yield of $8.97 \mathrm{t} \mathrm{ha}^{-1}$ [7] which is lower as compared to the world average of 18.8 ton $\mathrm{ha}^{-1}[8]$.

Planted under suitable environmental condition and agricultural management, high- quality true shallot seeds (TSS) have a high potential as an alternative planting material. The advantages of using TSS include, unbulky and 
less expensive planting materials, easier transportation, longterm storage capacity, production of healthy bulbs free of pathogens and larger bulbs, a shorter period between planting to harvesting time (depending on plant species and genotypes and environmental conditions in field or greenhouse the growth cycles can be shorter or longer), and higher yield [9, $10]$.

However, scarcity of high yielding varieties as well as lack of superior planting material seriously constrains productivity of the crop. The crop has degenerate seed production potential and it is usually established using bulbs. The perishability of the fleshy planting material and its sheer bulkiness and predisposition to fungal and viral disease creates difficulties in handling the material. What is more, large quantities of bulbs are required to plant a relatively small area of land, which exacerbates the problem of shortage of planting material. Also it is the edible part of the plant that is used for planting, which compromises the potential for consumption and marketing. Therefore, a research project was initiated aiming at studying adaption of true seed shallot for yield and components.

\section{Materials and Methods}

\subsection{Description of the Study Site}

The experiment was carried out under rain fed conditions at Kulumsa Agricultural Research Center during the rainy season for two consecutive years 2018 and 2019 cropping season (Table 1).

Table 1. Description of the study areas.

\begin{tabular}{ll}
\hline Descriptions & Kulumsa \\
\hline Altitude $(\mathrm{m})$ & 2200 \\
Latitude & $08^{\circ} 01^{\prime} 10^{\prime \prime} \mathrm{N}$ \\
Longitude & $39^{\circ} 09^{\prime} 11^{\prime \prime} \mathrm{E}$ \\
Rainfall $(\mathrm{mm})$ & 820 \\
Tmin $\left({ }^{\circ} \mathrm{C}\right)$ & 10.5 \\
Tmax $\left({ }^{\circ} \mathrm{C}\right)$ & 22.8 \\
Soil type & Clay soil (Luvisols)) \\
Soil p & 6 \\
\hline
\end{tabular}

\subsection{Description of Experimental Materials}

The experiment was conducted using 2 genotypes and 1 improved variety (Table 2).

Table 2. List of experimental materials included in the study.

\begin{tabular}{ll}
\hline Treatments & Remark \\
\hline DZ-SHT-157-1B & Genotype \\
DZ-SHT-1-28 & Genotype \\
Minjar & Improved variety \\
\hline
\end{tabular}

\subsection{Treatments and Experimental Design}

The experiment was laid out in a randomized complete block design with three replications. The experimental plot size was $7.2 \mathrm{~m}^{2}$ planted with 5 rows spaced $0.60 \mathrm{~m}$ to each other and $0.10 \mathrm{~m}$ plant to plant spacing in a row. The spaces between blocks and plots were $1.5 \mathrm{~m}$ and $1 \mathrm{~m}$, respectively.

\subsection{Data Collection and Measurement}

Data collected on plant

Number of splits/plant: data on this parameter was recorded as the average splits number counted from five plants per plot. Only splits that had directly grown from the mother tuber and acted as an independent plant above the soil were considered as main stems.

Data collected on plot basis

Marketable bulb yield (kg/ plot): was calculated by weighing all the bulbs which were free from defects, disease, crack, and other physiological disorders per net plot area

Unmarketable bulb yield (kg/plot): Was calculated by weighing all bulbs other than marketable from each plot.

Total bulb yield (kg/plot): was calculated as the sum of the weights of marketable and unmarketable bulb from the net plot area.

Total bulb yield (qt/ha): was calculated as the sum of the weights of marketable and unmarketable bulb from the net plot area and transformed to quintal per hectare.

\subsection{Data Analysis}

All data were subjected to analysis of variance (ANOVA) combined ANOVA over years using SAS software version 9.3 [11] using a general linear model (GLM) [12]. The comparison of genotypes and Variety were conducted based on pooled mean performance over the years using Least Significant Difference at a 5\% level of significance. Analysis of variance in randomized complete block design was computed using the following model: $Y i j=+r j+$ gi $+\varepsilon i j$ Where, $\mathrm{Yij}=$ the response of trait $\mathrm{Y}$ in the ith genotype and the $\mathrm{jth}$ replication $=$ the grand mean of trait $\mathrm{Y} \mathrm{rj}=$ the effect of the jth replication gi $=$ the effect of the ith genotype $\varepsilon i j=$ experimental error effect

\section{Result and Discussion}

Analysis of variance was computed for bulb yield and number of splits per plant over years. The combined analysis of variance results for marketable bulb yield (kg/plot), unmarketable bulb yield $(\mathrm{kg} / \mathrm{ha})$, total bulb yield $(\mathrm{kg} / \mathrm{plot})$ and total bulb yield ( $\mathrm{t} / \mathrm{ha}$ ) (Table 3 ). The results showed that the mean squares for main factors of genotype and year as well as interaction of genotypes $\mathrm{x}$ year were significant for marketable bulb yield (kg/plot). The overall marketable yield range of the shallot varieties was from 256.56- 171.49qtha ${ }^{-1}$ and the average number of splits per plants ranged from 84.72. The overall marketable yield range of the shallot lines was from 14-19t.ha 1, different bulb color and single shape of the bulbs accounted for high un marketability of the bulbs that caused such big difference in marketable and total yield The number of split bulbs (2.7-3.3) and TSS\% was not very much different between the lines. Shallot, as a plant belonging to the Aggregatum Group when grown from bulbs, can produce clusters with a large number of daughter bulbs, whereas when it is grown from seeds or seedlings clusters contain on average 1-3 bulb lets or plants produce only a 
single bulb like onion [13]. The improved Minjar shallot variety showed its superiority in marketable bulb yield (kg/plot), total bulb yield ( $\mathrm{kg} / \mathrm{plot})$ and total bulb yield $(\mathrm{t} / \mathrm{ha})$ yields genotypes (Table 4 ).

Table 3. Combined analysis of for marketable bulb yield (kg/plot), unmarketable bulb yield ( $\mathrm{kg} / \mathrm{ha}$ ), total bulb yield (kg/plot) and total bulb yield (t/ha) two years (2017/18 and 2018/19).

\begin{tabular}{|c|c|c|c|c|c|c|}
\hline Source Variation & DF & MB/Plt (kg) & UnmB/plt (kg) & tyb/plt (kg) & Ns/plant & tyb/ha (qt) \\
\hline Year & 1 & $494.55^{* *}$ & $7.86^{*}$ & $627.17 * *$ & 5.5 & $336060.82 * *$ \\
\hline Rep & 2 & 3.1 & 1.1 & 4.78 & 5.25 & 2563.61 \\
\hline Treatment & 2 & $28.1 *$ & 2.6 & $21.68 *$ & $17.70 *$ & $11621.93 *$ \\
\hline Year*Treatment & 2 & $10.64 *$ & 3.32 & 2.12 & 11.38 & 1164.2 \\
\hline Error & 10 & 2.3 & 1.1 & 4.76 & 3.36 & 2552.53 \\
\hline Mean & & 6.8 & 2.2 & 8.96 & 6.1 & 207.49 \\
\hline LSD & & 1.95 & 1.32 & 2.81 & 2.36 & 64.99 \\
\hline $\mathrm{R}^{2}$ & & 96.2 & 67.59 & 93.49 & 68.85 & 93.49 \\
\hline
\end{tabular}

DF, degree freedom, CV, coefficient of variation, LSD, least significant difference, MB, marketable bulb yield (kg/plot), UNMB, unmarketable bulb yield (kg/ha), TYB, total bulb yield ( $\mathrm{kg} / \mathrm{plot})$ and TYB, total bulb yield (t/ha)

Table 4. Mean for marketable bulb yield (kg/plot), unmarketable bulb yield ( $\mathrm{kg} / \mathrm{ha})$, total bulb yield ( $\mathrm{kg} / \mathrm{plot})$ and total bulb yield (t/ha) two years (2017/18 and 2018/19).

\begin{tabular}{lllll}
\hline Trt & MB/plt (kg) & UnmB/plt (kg) & tyb/plt (kg) & Ns/plant \\
\hline DZ. SHT157-1B & $6.90 \mathrm{~b}$ & $1.5 \mathrm{a}$ & $8.4 \mathrm{ab}$ & $4.72 \mathrm{~b}$ \\
DZ. SHT91-28 & $4.60 \mathrm{c}$ & $2.82 \mathrm{a}$ & $7.41 \mathrm{~b}$ & $194.44 \mathrm{ab}$ \\
Minjar & $8.92 \mathrm{a}$ & $2.20 \mathrm{a}$ & $11.1 \mathrm{a}$ & $5.48 \mathrm{~b}$ \\
\hline
\end{tabular}

MB, marketable bulb yield (kg/plot), UNMB, unmarketable bulb yield (kg/ha), TYB, total bulb yield (kg/plot) and TYB, total bulb yield (t/ha)

\section{Conclusion}

Three shallot varieties were compared at Kulumsa Agricultural Research Center using Randomized block Design with three replications. Analysis of variance was computed for bulb yield and number of splits per plant over years. The combined analysis of variance results for marketable bulb yield ( $\mathrm{kg} / \mathrm{plot})$, unmarketable bulb yield $(\mathrm{kg} / \mathrm{ha})$, total bulb yield $(\mathrm{kg} / \mathrm{plot})$ and total bulb yield $(\mathrm{t} / \mathrm{ha})$. The results showed that the mean squares for main factors of genotype and year as well as interaction of genotypes $\mathrm{x}$ year were significant for marketable bulb yield (kg/plot). The overall marketable yield range of the shallot varieties was from 256.56- 171.49 $\mathrm{qtha}^{-1}$ and the average number of splits per plants ranged from 8- 4.72. Improved Minjar shallot variety showed its superiority in marketable bulb yield (kg/plot), total bulb yield (kg/plot) and total bulb yield ( $\mathrm{t} / \mathrm{ha})$ yields as compared to other varieties. Therefore, as there was no significant yield advantage between these varieties from true seed study area, so the experiment could be repeated across locations to come up with good conclusion for recommendation.

\section{References}

[1] Wassu Mohammed, Kebede Woldetsadik and Bekele Kebede. (2018). Registration of a New "Improved Huruta" Shallot Variety with True Seed Production Potential. East Afri. J. Sci. 12: $77-82$.

[2] Tiru Tesfa, Kebede Woldetsadik and Wondimu Bayu. (2015). Shallot Yield, Quality and Shelf-life asAffected by Nitrogen Fertilizer, Int. J. Veg. Sci. 21: 454-466.
[3] Askari-Khorasgani, O. and Mohammad, P. (2019). Agricultural management and environmental requirements for production of true shallot seeds: a review. Adv. Plants Agric. Res. 9: 318-322.

[4] Shimeles Aklilu. (2014). The performance of true seed shallot lines under different environments ofEthiopia. J. Agri. Sci. 59: 129-139.

[5] Kebede Woldetsadik. (2003). Shallot (Allium cepa var. ascolonicum) Responses to Plant Nutrients and Soil Moisture in a Sub-humid Tropical Climate. PhD dissertation submitted to Swedish University of Agricultural Sciences, Sweden.

[6] Dessie Getahun. (2016). Bulb Placement Effects on Growth Performance and Yield of Shallot (Allium Cepa L. Aggregatum Group). International Journal of Research Studies in Agricultural Sciences (IJRSAS). Vo. 2 (8). PP 33-38.

[7] Central Statistical Agency of Ethiopia (CSA). (2017). Report on areas and production of crops (private peasant holding, meher season). The Federal Democratic Republic of Ethiopia Central statistical Agency. Addis Ababa: Statistical Bulletin.

[8] Food and Agriculture Organization Statistical Data Base (FAOSTAT). (2017). The agriculture data base http." Retrieved: http://faostat3.fao.org/faostatgateway/go/to/do wnload/Q/QC/E.Last.

[9] Agung IGAMS, Diara IW. (2017). Pre sowing Treatment Enhanced Germination and Vigour of True Shallot (Allium cepa var. aggregatum) Seeds. International Journal of Environment, Agriculture and Biotechnology. 2 (6): 32623267.

[10] Triharyanto E, Sudadi S, Rawandari S. (2018a). Adaptation of six shallots varieties to phosphate solubilizing bacteria on the flower formation, seeds fromation, and yields on the lowland. IOP Conference Series: Earth and Environmental Science. 142 (1): 012-067. 
[11] SAS Institute. (2010). SAS/STAT guide for personal computers, version 9.3 edition. SAS Institute Inc., Cary, NC.

[12] Gomez, K. A., and A. A. Gomez. (1984). Statistical Procedures for Agricultural Research. 2nd ed., John Wiley and Sons. Inc., New York, USA.
[13] Shimeles Aklilu and Lemma Dessalenge. (2015). The performance of true seed shallot lines under two methods of planting at different environments of Ethiopia. Research Journal of Agriculture and Environmental Management. Vol. 4 (3), pp. 174-179. 